Hill, J.R. and Groothuis, P.A. (2001), The New NBA Collective Bargaining Agreement, The Median Voter Model and a Robin-Hood Rent Redistribution. Journal of Sports Economics, 2(2): 131-144 (May 2001). Published by SAGE. doi:10.1177/152700250100200203

\title{
The New NBA Collective Bargaining Agreement, the Median Voter Model, and a Robin Hood Rent Redistribution
}

J. Richard Hill and Peter A. Groothuis

\begin{abstract}
In this article, it is suggested that the new collective bargaining agreement (CBA) in the National Basketball Association (NBA) redistributes rents from the superstars back to the median voters. In particular, it is suggested that portions of the new agreement, such as salary caps, are designed to improve the rather skewed distribution of salaries in the NBA. Evidence from a Lorenz curve analysis of the first 2 years under the new contract suggests that all players with salaries below the median wage gain from the new agreement, and those with salaries closest to the median wage gain the most. The analysis suggests that skewed salary distributions may lead to CBAs that redistribute the rents from the rich (superstars) to the poor (median voters).
\end{abstract}


Over the years, the primary goal of the unions representing professional athletes in baseball, football, hockey, and basketball has been the negotiation of free agency for the players. Under the old reserve system that prevailed in all sports, players' services were the sole properties of the clubs that first contracted them, typically following some sort of draft procedure. Under the reserve system, players were unable to increase their bargaining power during salary negotiations by threatening to play elsewhere. Rottenberg (1956) was the first to point out the monopsonistic exploitation inherent in this industry structure. Scully (1969) provided empirical estimates of the extent of the level of exploitation by Major League Baseball (MLB).

The Major League Baseball Players Association won free agency for its members as a result of a 1976 arbitration hearing. The National Basketball Players Association (NBPA) won free agency as a result of the Supreme Court's ruling in the Oscar Robertson case.1 Ultimately, the dissolution of the reserve system and the introduction of competitive bidding for free agents led to large salary increases for some players as well as freedom of choice in location. Free agency is now also available for professional football and hockey players.

The repeal of the perpetual reserve rule has allowed sports unions to increase the shares of team revenues accruing to the players. Likewise, resistance to hard salary caps and negotiations over the percentages of revenues allocated to salaries represent sports unions' efforts to expropriate larger shares of owners' monopoly profits for their members. In this respect, sports unions perform much the same function as the traditional monopoly face of unions as identified by Freeman and Medoff (1984) in their influential book, What Do Unions Do? In their book, however, Freeman and Medoff suggested that there are two faces of unions: the monopoly face and the collective voice face. They suggested that a union is not only a monopoly seller of labor but also a political force for its members. The collective voice model suggests that through collective bargaining, unions maximize the well-being of median workers. This model suggests less wage dispersion within union establishments, work rules that benefit more senior workers, and more clearly defined grievance and arbitration procedures.

In sports unions, the collective voice face seems to have been mostly dormant. Only two articles have addressed aspects of the median voter model in professional sports: Bishop, Finch, and Formby (1990), and White (1986). White (1986) suggested that the traditional median voter model explains aspects of the 1982 free agency agreement in the National Football League (NFL). Bishop et al. (1990) also analyzed the NFL agreement and suggested that a risk-averse median voter model explains the agreement better. In the National Basketball Association (NBA), unions have typically resisted negotiating many measures dealing with the internal distribution of salaries. The main exception to this statement is the establishment of a minimum salary. Another exception of more recent origin is the establishment of a scale for rookie salaries based on the player's place in the draft (Staudohar, 1996, pp. 106-126).

The new collective bargaining agreement (CBA) that emerged from the contentious negotiations between the NBPA and the NBA owners may prove to represent a turning point in sports unions' goals and a blueprint for upcoming negotiations in other sports. The hard caps placed on superstar salaries in the new NBA agreement 
combined with other aspects of the CBA appear to represent a shift by the union toward greater concern for the internal distribution of salaries. This development suggests that the implications of the median voter model have manifested themselves in a sports union much as they have been applied in traditional unions for decades.

\section{BACKGROUND}

Until the 1998-1999 season, the NBA had never canceled a game due to a labor dispute. The relationship between the NBPA and the owners seemed to be working well. In the 1983 CBA between the NBA owners and the NBPA, a salary cap was added to help restrain the upward spiral of player salaries. The quid pro quo to the players for their acceptance of the cap was a guaranteed percentage share of gross revenues from basketball-related income (BRI) (Staudohar, 1996, pp. 118-119). Gramlich (1994) called the salary cap system employed by the NBA an example of "communitarian capitalism." He proposed that the presence of a strong commissioner and a commitment by management and labor towork together to promote the common good of the sport had pulled the NBA out of a financial quagmire and made it a success. He contrasted this scenario with the picture of "individualistic capitalism" employed by MLB, in which the union and owners were unable to agree on a salary cap. The basic structure of the NBA compromise settlement lasted through two more collective bargaining negotiations for new agreements in 1988 and 1995, despite antitrust court cases, threats to decertify the union, and threats of a lockout. The rising popularity of the NBA created a surge in revenues from television broadcasts and attendance. Average player salaries soared along with NBA revenues. What happened to ruin the NBA's streak of no work stoppages?

The lockout in the NBA at the start of the 1998-1999 season implies that the form of capitalism used in the NBA was not as communitarian as suggested by Gramlich (1994). Like their counterparts in professional baseball, football, and hockey, NBA owners have not been able to curtail spending on free agent players. The salary cap that was started in 1983 was not a hard cap; several exceptions existed. The most egregious exception to the soft salary cap was called the Bird Exception, named after Larry Bird, of the Boston Celtics. The Bird Exception allowed a team to pay any amount of money to keep one of its own players who had become a free agent, without regard to the cap (National Basketball Association, 1995, p. 76). This exception was designed to allow teams to reward their superstar players so as to not lose them to another team in a bidding war. Instead, owners often overbid on other free agents to lure them away from their current teams, staying just under the cap, before negotiating with their own superstars. Of course, such teams' salary levels greatly exceeded the cap after their own superstars were signed to contracts, but this did not violate the agreement because of the Bird Exception. In most seasons, a majority of teams exceeded the cap. 2

Under the terms of the 1995 CBA between the NBA and the NBPA, the owners could terminate the agreement after the 1997-1998 season or any season thereafter if the percentage of BRI devoted to player salaries exceeded 51.8\% (National Basketball Association, 1995, p. 185). This threshold was exceeded in the 1997-1998 season; it is estimated that salaries and benefits were about $57.2 \%$ of BRI. Facing 
the likely retirement of Michael Jordan and a possible decline in NBA popularity and revenue, on March 23, 1998, the owners voted to exercise this option in the agreement and renegotiate for new terms. Following a few fruitless discussions in which the union adamantly opposed any attempt to replace the soft salary cap with a hard cap, the owners imposed a lockout.

Negotiations for the union were led by G.William Hunter, executive director of The NBPA, and the union's president, Patrick Ewing. Hunter and Ewing were joined on the union's negotiating team by Alonzo Mourning, among others. Both Ewing and Mourning are NBA players who are represented by agent David Falk, who also represented other superstar players such as Michael Jordan. Many observers of the negotiations felt that Falk and/or the interests of a few superstars were dominating the union's position (Starr \& Samuels, 1999, p. 49). Hunter summoned players to New York on January 5 to show support for the union bargaining team's hard-line stance against a hard cap. Instead, the majority of players seemed to feel the same as one veteran all star, who was quoted as saying, "We told [Hunter]. 'Go in and get a deal and leave the two angry brothers [Ewing and Mourning] at home' " (Starr \& Samuels, 1999, p. 49). On January 6, 1999, a new, 6-year agreement was finally reached, just a day before the so-called drop-dead date proposed by the NBA's commissioner, David Stern, when the rest of the season would be canceled (Pedulla, 1999).

This compromise agreement represents an interesting case study in the politics of collective action. The players were represented at the negotiating table primarily by highly paid individuals who stood to lose a great deal in future compensation if the Bird Exception were deleted from the agreement. The concerns of the average wage earner in the NBA initially did not seem to be of prime concern to the union's leadership. The owners also had some divergent agendas at the bargaining table. Although all the owners wanted some means to control their costs, owners of small-market franchises might have wanted hard salary caps on overall team payrolls so they could reach profitability, and owners of large-market teams that were profitable might have wanted merely to contain the upward salary spiral while not losing their superstar players because of hard caps.

Somehow, the process of intraorganizational bargaining within the owners' and players' groups and interorganizational bargaining between these groups led to the median wage earner in the NBA becoming a focal point in the NBA negotiations.3 The following quotation is from a published letter dated December 17, 1998, written by G.William Hunter to all NBA players in response to a memo by David Stern. The quotation makes it clear that the union's chief negotiator expected proposals for the new CBA to address the growing skewness in player earnings:

The owners' proposals have done next to nothing to try to restore the middle class, our primary goal in this round of bargaining. Stern heralds the purported increases in the average salary which are significantly lower than the percentage increases we enjoyed in recent years, especially once the players' BRI is cut to $52 \%$ in three years-but doesn't dare make any projections about the growth of the median salary. . . . As we have said all along, we already have agreed to make enormous compromises for high-end players and remain willing to negotiate even further but only if this sacrifice will result in improved salaries for the lower and middle earning players. (Hunter, 1998) 
This development in the NBA negotiations came as little surprise to some observers of sports unions. Fort and Quirk (1995) noted in an article in the Journal of Economic Literature on professional sports leagues that "the fact that free agency has led to a more skewed distribution of player salaries in baseball raises some interesting questions as to negotiating positions unions might take in the future" ( $p$. 1297). Although Fort and Quirk (1995) were discussing a different sport, the same conclusion could obviously apply to basketball. The question that remains to be answered is whether or not the new provisions incorporated into the new NBA CBA will go far enough to correct this salary skewness. Gramlich (1994)would probably describe the new agreement as an even greater example of communitarian capitalism representing even greater cooperation between labor and management. Others might suggest that the voice of the median voter in the union has finally surfaced. 4

\section{THE MEDIAN VOTER MODEL AND THE NEW NBA CBA}

The median voter model has become the dominant model with which to analyze collective bargaining. Parson (1992) stated that "decision making in U.S. is collective and democratic suggesting that voting models are the appropriate tools of analysis for union behavior" (p. 439). Parson further suggested that "this insight is hindered by the fact that majority rule voting among self-interested voters over multidimensional issues such as those faced by a union electorate-wages, employment, and other working conditions-does not generally yield a voting equilibrium" (p. 439). Many variations of the median voter model have been developed to provide insights into which voting equilibrium will arise. We suggest that the new NBA CBA provides a case study with which to test the implications of various manifestations of the median voter model that have been developed to better understand union decisions.

Many authors have used the median voter model to analyze union behavior. White (1982), using a rational, self-interested median voter model, suggested that the within-union wage structure would be changed to increase the shares of the total wage bill received by median members of the bargaining unit. Black and Parker (1985) suggested that older workers reap more of the rents of unionization than younger workers because median voters approve seniority-based layoff rules. Parson (1992) suggested that union members tend to be egalitarian in nature and not strictly self-interested. He suggested that median voter models must incorporate aspects of egalitarian nature when voters will approve of contracts that do not necessarily benefit themselves but instead benefit individuals lower in the wage distribution. Bishop, Formby, and Smith (1991) suggested that a risk-averse median voter decision would rely not only on the expected rents received but on the distribution of rents. They suggested that a median voter would trade reduced risk (wage dispersion) for return. In a related article, Bishop et al. (1990) suggested that NFL players are risk averse in their preference for free agency.

To focus our analysis of the new NBA CBA, we developed the following questions from predictions of the various median voter models. First, are NBA players rationally self-interested, as suggested by White (1982), or are they egalitarian, as suggested by Parson (1992)? Second, do more tenured players gain at the expense of less tenured players, as suggested by Black and Parker (1985)? Third, are NBA 
players more risk averse in their decision making, as suggested by Bishop, Formby, et al. (1991)? To analyze these questions, we developed a model of union decision making that incorporates both the market forces of free agency and the median voter forces of rent sharing.

In sports unions, pay is determined more by performance and to a fairly lesser extent by seniority.5 Players are cut or released from teams based on ability and performance, not seniority. In Equation 1, we formally model a player's wage.

$$
W=M R P+r
$$

where a player's wage $(W)$ is determined by two components: the player's marginal revenue product (MRP) and the player's share of the rent $(r)$.We assume that $r$ can be both positive and negative. An example of a negative rent paid to a player is the amount of labor exploitation in a traditional monopsony model. We also suggest that the new CBA imposes a negative rent share on superstar salaries.

We specify the monopoly face and collective voice face of unions with two differing objective functions derived from a wage equation. From this wage equation, we can develop two union objective functions: the traditional monopoly objective function and the median voter objective function. The traditional monopoly objective function is

$$
\operatorname{Max} \sum r
$$

in which the union's objective function is to maximize the sum of the rents that accrue to its members. We argue that this has been the primary objective function of sports unions in the past.

The second objective function that arises within unions is the median voter objective function:

$$
\operatorname{Max} M R P k+r k
$$

where $k$ is the $k$ th player in the wage distribution. In this objective function, the $M R P$ is determined by the market, and $r$ is determined by the CBA.

Considering the various median voter models, we suggest that if a voter is rationally self-interested, $r$ will increase as the $k$ th member nears the median income position. This predicts that the greatest gains will be found in the 50th percentile of a Lorenz curve. Furthermore, if voters are rationally self-interested, $r$ should be greater for existing members and lowest for members who just joined the union. If voters are egalitarian, $r$ should be at least as great for the players at the bottom of the wage distribution as for those at the median position. If voters are risk averse, the variation of the overall wage distribution $(M R P+r)$ should fall. The risk-averse median voter model also suggests that there are times when the median wage will fall as long as the variation in income is more than offset by the lowering of the median wage.

To test the implications of the various median voter models, we compared aspects of traditional unions to certain elements of the new NBA CBA that illustrate attempts to appease median voters. In many traditional unions today, new hires find 
that they are paid according to a lower scale than more veteran workers. The difference in such pay is not merely the result of seniority pay increments; it stems from the use of two-tiered pay systems. Many unions accept lower pay scales and/or benefits for new hires during negotiations to preserve better terms for existing members. This behavior obviously bolsters the case of the median voter model in unions. A similar element exists in the new NBA agreement. Both the old and new CBAs call for 3-year rookie contracts determined by a scale. The scale is used to set the salary in each of the first 3 years of a player's tenure in the NBA based on when he was chosen in the first round of the draft. The salary scale over the 3-year period is lower under the new CBA.6 Also, under the new CBA, teams hold an option for a 4th year after the 3-year rookie scale contract expires and the right of first refusal for the 5th year; previously, first-round draft picks could opt for unrestricted free agency after the expirations of their rookie scale contracts. For second-round draft picks, teams will have rights of first refusal until the players accrue 3 years of experience; under the old agreement, such players were unrestricted free agents following the expirations of their first NBA contracts. Also, first-round draft picks such as Kevin Garnett will no longer be able to negotiate extensions to their rookie scale contracts after only their second season in the NBA. Now, such players cannot negotiate extensions to their rookie scale contracts until their option year. Thus, provisions of the new CBA support Black and Parker's (1985) model: The union voters distribute the rents from the players with less seniority to the players with more years in the league.

No maximum limits existed under the old agreement for individual player salaries. Under the new CBA, the maximum annual salary is $\$ 9$ million, or $25 \%$ of the salary cap, for players with 0 to 6 years of experience; $\$ 11$ million, or $30 \%$ of the cap, for players with 7 to 9 years of experience; and $\$ 14$ million, or $35.5 \%$ of the cap, for players with 10 or more years of experience. A player in the 1st year of a new contract can earn either $105 \%$ of his previous season salary or the applicable maximum described above, whichever is greater. Annual pay raises are restricted to $10 \%$ for most players and $12 \%$ for "Bird free agents" under the new CBA. Under the previous agreement, salary increases were limited to $20 \%$ each year with some exceptions. 
TABLE 1: Players Earning Salaries Above the New Caps

\begin{tabular}{lccc}
\hline \hline Player & $\begin{array}{c}\text { Date } \\
\text { Contract Signed }\end{array}$ & $\begin{array}{c}1998-1999 \\
\text { Salary }\end{array}$ & $\begin{array}{c}\text { Maximum for New Contract } \\
\text { Under New CBA }\end{array}$ \\
\hline Patrick Ewing & $7 / 2 / 97$ & $\$ 18,500,000$ & $\$ 14,000,000$ \\
Shaquille O’Neal & $7 / 18 / 96$ & $\$ 15,000,000$ & $\$ 9,000,000$ \\
David Robinson & $12 / 6 / 95$ extension & $\$ 14,841,000$ & $\$ 11,000,000$ \\
Kevin Garnett & $10 / 1 / 97$ & $\$ 14,000,000$ & $\$ 9,000,000$ \\
Alonzo Mourning & $8 / 10 / 96$ & $\$ 13,130,000$ & $\$ 9,000,000$ \\
Juwan Howard & $8 / 5 / 96$ & $\$ 13,125,000$ & $\$ 9,000,000$ \\
Dikembe Mutombo & $7 / 15 / 96$ & $\$ 11,218,000$ & $\$ 11,000,000$ \\
Chris Webber & $10 / 9 / 95$ & $\$ 10,000,000$ & $\$ 9,000,000$ \\
\hline
\end{tabular}

SOURCE: Bender (n.d.).

NOTE: CBA = collective bargaining agreement.

a. These figures represent the maximums for players who would be negotiating new contracts at substantially higher salaries than they were previously earning. Players can earn the maximum amount listed or

$105 \%$ of their previous year salaries in the last year of their contracts.

TABLE 2: New Contracts Signed at Maximum Limit

\begin{tabular}{lccc}
\hline \hline Player & $1998-1999$ Salary & Years in League & 1999-2000 Salary \\
\hline Jayson Williams & $\$ 11,000,000$ & 8 & \\
Arvydas Sabonis & $\$ 9,000,000$ & 3 & \\
Damon Stoudamire & $\$ 9,000,000$ & 3 & \\
Antonio McDyess & $\$ 9,000,000$ & 4 & $\$ 9,000,000$ \\
Ray Allen & & 2 & \\
\hline
\end{tabular}

SOURCE: Bender (n.d.).

These maximum limits will undoubtedly be constraining on the salaries and mobility of superstar free agents. 7 Table 1 lists the players who were earning above these limits when the new agreement was reached. Table 2 lists the players who negotiated salaries at the maximum allowable levels after the new CBA went into effect. The salary savings generated in the future from these individual pay constraints will be sizable. The union made it clear during negotiations that the quid pro quo for these limits are provisions to improve the salaries of median-income wage earners, supporting White's (1986) self-interest median voter model of unions.

Under the terms of the 1995 agreement, minimum salaries of $\$ 242,000$ for rookie players and $\$ 272,500$ for veteran players were established for the 1997-1998 season. The new CBA calls for a sliding scale minimum wage based on years of service. The minimum wage for rookies is set at $\$ 275,000$ and increases for each additional year of service in the league up to a maximum of $\$ 1$ million for players with 10 years of experience.8 A veteran player with 10 or more years of experience such as Joe Klein, who played sparingly for the Chicago Bulls in the 1997-1998 season for $\$ 272,500$, would earn over $\$ 700,000$ more under the new agreement. 
This provision obviously appeals to veteran, journeyman players. To prevent teams from choosing lower priced rookie players over higher priced veterans, the compensation for players with 5 or more years of experience above the pay for a player with 4 years of experience is paid out of a league wide fund created and maintained by the NBA (see National Basketball Association, 1995, Article IV, Section $1[1][1]$, pp. 39-40). This portion of the new agreement not only enhances the pay of a portion of the lowest earners in the NBA but also injects a dose of seniority pay into the pay structure, further supporting Black and Parker's (1985) model.

Salary cap exceptions in the new CBA also demonstrate direct appeal to median voters. The previous CBA contained several exceptions to the salary cap. The most controversial exception to the soft cap from the owners' perspective was the previously mentioned Bird Exception. In addition to the Bird Exception, exceptions for disabled players' replacements, assigned players acquired through trades, rookie scale contracts, contracts at the league's minimum salary, and a \$1 million exception were also included in the CBA. This last exception could not be used in consecutive seasons.

Under the new agreement, all of the previous exceptions to the team salary cap remain; the only qualification to the exceptions is that individual salaries cannot exceed the maximum individual caps previously mentioned. In addition, a "midlevel" exception has been added. The midlevel exception is $\$ 1.75$ million in the 1st year of the CBA and increases to $108 \%$ of the average salary for the prior season by the end of the CBA. It can be used in each season. This exception is designed to increase the salaries of middle-class players in terms of the salary distribution, further supporting White's (1986) self-interest median voter model.

The biggest potential sacrifice by the players in the new CBA is the salary recovery provision, which becomes operative if collective salaries exceed a specified percentage of $\mathrm{BRI}$. The determination of what constitutes $\mathrm{BRI}$ is a negotiation nightmare. In the past, teams underreported revenues for this calculation through the accounting complexities of joint ownership of a team and a broadcast station. The Bird Exception made this practice somewhat a nonissue because the cap was soft, not hard. The new agreement does not have a set percentage for the first 3 years but calls for salaries to be no more than $55 \%$ of revenues in the 4 th, 5 th, and 6 th years and no more than $57 \%$ of revenues in the 7 th year, if owners exercise their option to extend the agreement. If salaries exceed the cap limit, the CBA calls for the NBA to recover the excess pay by levying an escrow tax of equal percentage amounts on the compensation of all "adjustment players." The addition to the CBA of excess salary recovery by the owners makes the calculation and inclusion of all relevant revenue for BRI extremely important. All players, except those who sign one or two 10-day contracts, are considered adjustment players unless the union decides on an alternative method for recovery of the overspending. Theoretically, the agreement would allow for the union to use this mechanism to further address the issue of salary inequity. Current projections of player salaries and BRI for the 2001-2002 season suggest that the excess salary recovery plan will be necessary. 9

This part of the agreement suggests that the median voters and team owners formed a coalition to shift rents received by superstar players and allocate them between team owners and median voters. 
It is clear that the new NBA agreement has added provisions designed to improve the skewed distribution of salaries. We now examine evidence from the 1998-1999 and 1999-2000 seasons to determine the effects of these measures.

\section{NBA SALARY DISTRIBUTION DATA}

In Tables 3 and 4, we analyze how the new CBA changed the distribution of wages in the NBA. In Table 3, we provide details on the distribution ofwages in the NBA using basic descriptive statistics, and in Table 4, we provide Lorenz curves and Gini coefficients, the traditional tools used to analyze income inequality. The data in Table 3 clearly show the unequal distribution of salaries in the NBA. The growth of the mean salary in theNBAfrom the 1993-1994 season to the 1997-1998 season was approximately $78.5 \%$, whereas the median salary rose by only $31.3 \%$. The value of the standard error has shown enormous growth. The positive measure of skewness indicates that the salaries above the average are more dispersed than those belowthe average.10 Note the huge rise in this measure during this period. The positive values for kurtosis indicate that the salary distribution is more peaked around its center than a normal curve; some salaries in the league are far from the mean relative to other salaries.11

Data from the 1998-1999 and 1999-2000 seasons indicate some improvement in the area of income inequality and skewness in the NBA. The value of the measures for skewness and kurtosis dropped substantially in the 1998-1999 season and fell even further in the 1999-2000 season.12 The gap between the mean and median salaries worsened slightly in the 1998-1999 season, but the gap stayed the same in the 1999-2000 season. The reason for the slight change might be that only 184 of the 422 players in the salary distribution signed new agreements in 1999. The majority of players had already signed multiyear contracts before the negotiation of the new CBA. In fact, the mean salary for those who signed contracts in 1999 was only $\$ 1,529,768$, compared with an average of $\$ 3,166,623$ for contracts signed before 1999. Obviously, the new signings are much more heavily tilted toward the lower pay scale, with 34 rookies signing contracts at the league minimum of $\$ 287,500$ and 15 signing contracts at the minimum of $\$ 350,000$ for players with 1 year of experience. Restricting the sample to players with more than 2 years of experience, however, reveals an even greater gap in means; players signing new agreements have an average salary of $\$ 1,935,633$, whereas players who had signed an agreement prior to the 1999 negotiations have an average salary of $\$ 4,284,542$. 
TABLE 3: Salary Distribution Figures for Selected Seasons

\begin{tabular}{|c|c|c|c|c|c|c|c|c|c|}
\hline & $\begin{array}{c}\text { NBA } 1993- \\
1994\end{array}$ & $\begin{array}{c}\text { NBA } 1994- \\
1995\end{array}$ & $\begin{array}{c}\text { NBA } 1995- \\
1996\end{array}$ & $\begin{array}{c}\text { NBA } 1996- \\
\quad 1997\end{array}$ & $\begin{array}{c}\text { NBA 1997- } \\
1998\end{array}$ & $\begin{array}{c}\text { NBA } 1998- \\
1999\end{array}$ & $\begin{array}{c}\text { NBA } 1999 . \\
2000\end{array}$ & $\begin{array}{c}\text { NHL } 1998- \\
\quad 1999\end{array}$ & $\begin{array}{l}M L B \\
1999\end{array}$ \\
\hline Minimum & $\$ 150,000$ & $\$ 150,000$ & $\$ 225,000$ & $\$ 247,500$ & $\$ 272,500$ & $\$ 287,500$ & $\$ 301,875$ & $\$ 150,000$ & $\$ 200,000$ \\
\hline Maximum & $\$ 5,740,000$ & $\$ 7,300,000$ & $\$ 18,724,000$ & $\$ 30,140,000$ & $\$ 33,140,000$ & $\$ 18,500,000$ & $\$ 17,142,858$ & $\$ 14,000,000$ & $\$ 11,949,794$ \\
\hline Mean & $\$ 1,293,962$ & $\$ 1,465,546$ & $\$ 1,700,352$ & $\$ 2,067,078$ & $\$ 2,310,130$ & $\$ 2,456,919$ & $\$ 3,162,024$ & $\$ 1,143,465$ & $\$ 1,708,010$ \\
\hline Median & $\$ 1,100,000$ & $\$ 1,184,000$ & $\$ 1,300,000$ & $\$ 1,355,000$ & $\$ 1,444,000$ & $\$ 1,460,500$ & $\$ 2,000,000$ & $\$ 700,000$ & $\$ 700,000$ \\
\hline Standard deviation & $\$ 976,949$ & $\$ 1,118,351$ & $\$ 1,652,787$ & $\$ 2,507,458$ & $\$ 2,874,019$ & $\$ 2,714,989$ & $\$ 3,228,859$ & $\$ 1,234,819$ & $\$ 2,117,864$ \\
\hline Skewness & 1.12 & 1.31 & 3.58 & 4.91 & 4.72 & 2.35 & 1.85 & 3.50 & 1.79 \\
\hline Kurtosis & 1.30 & 2.71 & 27.89 & 43.17 & 37.59 & 6.87 & 3.42 & 20.15 & 3.23 \\
\hline
\end{tabular}

SOURCE: Bender (n.d.) for NBA data; National Hockey League Players' Association (2000) for NHL data; and Bodley (1999, p. 16C) for the MLB data. NOTE: NBA = National Basketball Association, NHL = National Hockey League, MLB = Major League Baseball.

TABLE 4: Lorenz Curve Calculations

\begin{tabular}{|c|c|c|c|c|c|c|c|}
\hline & $\begin{array}{c}N B A \\
1993-1994\end{array}$ & $\begin{array}{c}N B A \\
1994-1995\end{array}$ & $\begin{array}{c}N B A \\
1995-1996\end{array}$ & $\begin{array}{c}N B A \\
1996-1997\end{array}$ & $\begin{array}{c}\text { NBA } \\
1997-1998\end{array}$ & $\begin{array}{c}N B A \\
1998-1999\end{array}$ & $\begin{array}{c}\text { NBA } \\
1999-2000\end{array}$ \\
\hline First quintile ordinate & $.0352(.0030)$ & $.0272(.0020)$ & $.0308(.0015)$ & $.0254(.0017)$ & $.0274(.0020)$ & $.0309(.0019)$ & $.0319(.0024)$ \\
\hline Second quintile ordinate & $.1357(.0069)$ & $.1171(.0070)$ & $.1114(.0070)$ & $.0960(.0076)$ & $.0964(.0070)$ & $.0979(.0053)$ & $.1039(.0062)$ \\
\hline Third quintile ordinate & $.3010(.0103)$ & $.2816(.0111)$ & $.2622(.0118)$ & $.2310(.0135)$ & $.2257(.0131)$ & $.2159(.0102)$ & $.2326(.0101)$ \\
\hline Fourth quintile ordinate & $.5586(.0110)$ & $.5447(.0125)$ & $.5155(.0163)$ & $.4645(.0213)$ & $.4573(.0210)$ & $.4459(.0154)$ & $.4553(.0136)$ \\
\hline Number of observations & 382 & 393 & 420 & 385 & 409 & 424 & 393 \\
\hline Gini coefficient ${ }^{2}$ & .41 & .43 & .46 & .51 & .52 & .52 & .50 \\
\hline
\end{tabular}

NOTE: NBA = National Basketball Association. Numbers in parentheses are standard deviations.

a. The formula for the Gini coefficient can be found in Buchanan and Slottje (1996, p. 65).

To further analyze how the new CBA influenced the distribution of wages in the NBA, we calculated the Lorenz curves and the Gini coefficients for the 5 years prior to the new contract and the 2 years after the contract. In the 5 years prior to the new contract, wage dispersion grew substantially, with the Gini coefficient growing from .41 in the 1993-1994 season to .52 in the 1997-1998 season, just prior to the new CBA. Using the Lorenz curves and the stochastic dominance test, we found that the 1993-1994 season dominates the 1997-1998 season for all ordinates.13 The Lorenz curve analysis suggests that salary dispersion was worsening just prior to the agreement: Whereas $60 \%$ of the players earned $30.1 \%$ of the income in the 1993-1994 season, they earned only $22.6 \%$ of the income in the 1997-1998 season. For the 1999-2000 season, 2 years after the CBA, the Lorenz curve analysis suggests that wage dispersion fell, with the 1999-2000 season stochastically dominating the 1997-1998 season for all ordinates except the fourth ordinate. Thus, for the first three ordinates, the players in the lower $60 \%$ of the wage distribution gain in percentage of income earned, whereas those in the top $40 \%$ of the wage distribution lose in percentage of income earned. The Lorenz curve analysis supports both White's (1986) model of rational self-interest and Parson's (1992) egalitarian median voter model. That is, median voters and players in the lower end of the wage distribution gain rents, whereas those in the top end of the wage distribution lose rents. Overall, the data suggest that the new CBA has narrowed the wage distribution in the NBA, with the greatest gains going to the median voters. 


\section{SUMMARY AND CONCLUSIONS}

During negotiations for the latest CBA, the NBPA leadership focused the latter rounds of discussion on the skewness of the NBA's salary distribution. The proposals by the union suggest that the union leaders are finally responding to the voice of the median voters. The median voters, motivated by rational self-interest and egalitarianism, shift rents from the superstars to everybody else. In addition, we suggest that many of the provisions of the new CBA attempt to raise the salaries of lower paid players in the league, whereas others place a hard cap on the salaries of superstars. The evidence from the first two seasons under the new agreement suggests some mild improvement in the salary distribution. With the number and length of long-term contracts, even mild improvements suggest that the CBA has been successful in correcting the skewness of the NBA's salary distribution. The union's decisions on the taxation of adjustment players' salaries to correct for overpay in future seasons, should such measures become necessary, will give an indication of the sincerity of its leadership in addressing this issue.

The upcoming negotiations in other professional sports will undoubtedly be affected by the latest NBA agreement. It will be interesting to see if the members of other sports unions push for more egalitarian salary distributions at the start of negotiations or whether management ties this issue to salary caps.

\section{NOTES}

1. For details on how free agency was achieved in professional baseball, football, basketball, and hockey, see Staudohar (1996).

2. Salary data (Bender, n.d.) indicate that for the 1993-1994 season, only 1 team was under the cap; for the 1994-1995 season, no teams were under the cap; for the 1995-1996 season, 12 teams were under the cap; for the 1996-1997 season, 4 teams were under the cap; for the 1997-1998 season, 8 teams were under the cap; and for the 1998-1999 season, 2 teams were under the cap.

3. In this article, we focus on the new agreement from the perspective of the players. It is clear from the negotiations that the owners manipulated the situation to pit the median voters against the superstars to gain more economic rent.

4. It is difficult to precisely characterize the median voter in the NBA. The players who occupy the 50th percentile of the salary distribution are a mixed lot. Some of these players are in the midst of a rookie scale contract and may be rising stars who will skyrocket to the upper income levels on reaching free agency. These players were not members of the union when they signed their initial contracts. The players to whom the union tried to appeal with the provisions of the latest CBA are the veterans who are not stars. Such players probably have approximately 5 or more years of experience and are role players. They may or may not be starters on their teams. If they start, they are probably defensive stoppers, rebounders, or playmakers, not major scorers.

5. Hill and Spellman (1984) found that the introduction of free agency into major league baseball caused a decrease in the level of pay based on years of service and an increase in pay based on level of performance. 
6. For instance, the sum of the rookie scale salaries (1999-2000 + 2000-2001 + 2001-2002) for the first pick in the draft in 1999 is $\$ 881,700$ less under the new agreement compared with the exact same figures under the old agreement. See Exhibit B in National Basketball Association (1995, 1999).

7. Boeck (1999) reported that Shaquille O'Neal, of the Los Angeles Lakers, would sacrifice millions of dollars if he chose to exercise the opt-out clause in his multiyear deal, because of the new CBA. If he exercised his option and left the Lakers after the 1998-1999 season, the most he could earn with a new club in the 1999-2000 season would be $105 \%$ of his 1998-1999 salary, or \$15.75 million, compared with the \$17.1 million that the Lakers will pay him if he stays.

8. For the full minimum annual salary scale, see Exhibit C in National Basketball Association (1999).

9. At its annual meeting in July 2000, the NBPA told players that current projections for the 2001-2002 season placed salaries at $64 \%$ of BRI, well above the $55 \%$ trigger level for excess pay recovery. Players were told to prepare for a $10 \%$ escrow tax on their salaries for that season. Apparently, no alternative plans were discussed for the excess pay recovery (see Wyche, 2000).

10. The measure of skewness used equals $[n /(n-1)(n-2)] \times \Sigma[(x j-x) / s] 3$, where $s$ is the standard deviation, $x$ is the mean, and $n$ is the sample size.

11. The measure of kurtosis used equals $\{[n(n+1) /(n-1)(n-2)(n-3)] \times \Sigma[(x j-x) / s] 4\}-[3(n-$ $1) 2$ / $(n-2)(n-3)$ ], where $s$ is the standard deviation, $x$ is the mean, and $n$ is the sample size.

12. Most of the reduction of the measure of skewness and kurtosis in the 1998-1999 season was due to the retirement of Michael Jordan and the removal of his $\$ 33$ million salary.

13.We used the distribution-free statistical inference $t$ test developed by Beach and Davidson (1983) for Lorenz curves, which was first applied to sports by Porter and Scully (1996). First, we calculated the relevant standard error for each ordinate. Then, we calculated a comparison of ordinates over time.We found that with the exception of two crossings, early Lorenz curves (for the 1993-1994 season) stochastically dominate those just prior to the new CBA. We then found that the Lorenz curve for the 2 years after the new CBA stochastically dominates for the first three ordinates (through the $60^{\text {th }}$ percentile).

\section{REFERENCES}

Beach, C. M., \& Davidson, R. (1983). Distribution-free statistical inference with Lorenz curves and income shares. Review of Economic Studies, 50, 723-735.

Bender, P. (n.d.). Patricia's various basketball stuff [Online]. Available: http://www.dfw.net/ patricia

Bishop, J., Finch, J. H., \& Formby, J. P. (1990). Risk aversion and rent-seeking redistributions: Free agency in the National Football League. Southern Economic Journal, 57(1), 114-124.

Bishop, J. A., Formby, J. P.,\&Smith,W. J. (1991). International comparisons of income inequality: Test for Lorenz dominance across nine countries. Economica, 58, 461-477. 
Black, D. A., \& Parker, D. (1985). The division of union rents. Journal of Labor Research, 6(3), 281-288.

Bodley, H. (1999, November 19). Highest-paid players by position. USA Today, p. 16C.

Boeck, G. (1999, January 11). Labor deal includes a benefit for Lakers. USA Today, p. 8C.

Buchanan, M. J., \& Slottje, D. J. (1996). Advances in the economics of sport, supplement 1, 1996: Pay and performance in the NBA. Greenwich, CT: JAI.

Fort, R., \& Quirk, J. (1995). Cross-subsidization, incentives, and outcomes in professional team sports leagues. Journal of Economic Literature, 23, 1265-1299.

Freeman, R. B., \& Medoff, J. L. (1984). What do unions do? New York: Basic Books.

Gramlich, E. M. (1994). A natural experiment in styles of capitalism: Professional sports. Quarterly Review of Economics and Finance, 34(2), 121-130.

Hill, J. R., \& Spellman,W. (1984,Winter). Professional baseball: The reserve clause and salary structure. Industrial Relations, 22, 1-19.

Hunter, G. W. (1998, December 17). Hunter's response to Stern's letter [Online]. Available: http://cbs.sportsline.com/u/page/covers/basketball/dec98/hunterresponse121798.htm

National Basketball Association. (1995, September). NBA collective bargaining agreement. New York: Author.

National Basketball Association. (1999, January). NBA collective bargaining agreement. New York: Author.

National Hockey League Players' Association. (2000). The official site of the NHLPA [Online]. Available: http://www.nhlpa.com

Parson, D. O. (1992). The internal distribution of union rents: An empirical test of the voting power model. Review of Economics and Statistics, 73, 439-444.

Pedulla, T. (1999, January 7). Players relieved they will be playing again. USA Today, p. 4C.

Porter, P. K., \& Scully, G. W. (1996). The distribution of earnings and the rules of the game. Southern Economic Journal, 63(1), 149-162.

Rottenberg, S. (1956, June). The baseball players' labor market. Journal of Political Economy, $64,242-258$.

Scully, G. (1969). Pay and performance in major league baseball. American Economic Review, $64,915-930$.

Starr, M., \& Samuels, A. (1999, January 18). Taking it hard to the NBA hoop. Newsweek, pp. 48-50. 
Staudohar, P. D. (1996). Playing for dollars: Labor relations and the sports business. Ithaca, NY: Cornell University Press.

White, M. D. (1982). The intra-unit wage structure and unions: A median voter model. Industrial and Labor Relations Review, 35(4), 565-577.

White, M. D. (1986). Self-interest redistribution and the National Football League Players Association. Economic Inquiry, 24, 669-681.

Wyche, S. (2000, July 27). "I don't think anybody's happy about it”; NBA players brace for escrow tax. The Washington Post, p. D3. 